Caroline Dwiseptianti, Febri Adi Susanto, Yekti Asih Purwestri, Tri Rini Nuringtyas. (2019). Optimasi Metode 1H-NMR Profiling pada RImpang Kunyit (Curcuma Longa L.). Journal Bioeksperimen. Vol. 5 (2) Pp. 106-113. Doi: 10.23917/bioeksperimen.v5i2.2795

\title{
OPTIMASI METODE 1H-NMR PROFILING PADA RIMPANG KUNYIT (CURCUMA LONGA L.)
}

\author{
Caroline Dwiseptianti, Febri Adi Susanto*, Yekti Asih Purwestri, Tri Rini Nuringtyas* \\ Laboratorium Biokimia, Fakultas Biologi, Universitas Gadjah Mada \\ *Email: tririni@ugm.ac.id; febri.adi.s@mail.ugm.ac.id \\ Paper diterima : 23 Januari 2018, Paper publish : September 2019
}

\begin{abstract}
The use of medicinal plants is increasing due to the lack of side effects caused and the number of bioactive compounds that cannot be represented by synthetic chemical synthesis compounds. However, the management and use of natural medicines for the main handling of diseases are often hampered by the quality of the ingredients which are low and unstable. The standardized quality control system of OAI (Indonesian Natural Medicine) is the main key to improve clinical assurance and safety of the use of herbal medicines in Indonesia. One of the medicinal plants known to the public is Curcuma longa L. (turmeric). The main active components contained in turmeric are curcumin, demetoksikurkumin, bis-demetoksikurkumin, and ar-turmeron. Information about the quality of turmeric is needed in its use as a raw material for drugs so we need an analytical technique that is able to identify the diversity of metabolite profiles of active compounds. In this research, an optimization method is used to improve efficiency in the extraction of turmeric rhizome metabolites so that the best solvent concentration is known for the analysis of fingerprinting secondary metabolites with $1 \mathrm{H}-\mathrm{NMR} 500 \mathrm{MHz}$ spectroscopy in turmeric rhizomes. The results were analyzed with MNOVA software and chemical shift obtained compared with the reference. From the results obtained a concentration of methanol-d4 (CD3OD) 100\% able to extract curcumin better than other solvents. The solvent is able to extract saccharide (sugar) compounds in the form of sucrose, amino acids and fatty acids in the form of methionine, glutamine, acetate, and glycero phospho choline.
\end{abstract}

Key words: Curcuma longa, $1 H-N M R$, Metabolomics, curcumin

\section{Pendahuluan}

Masyarakat Indonesia secara luas telah mengkonsumsi Obat Alam Indonesia (OAI) sejak beratus tahun lamanya. Data WHO menunjukan pada tahun 2008 sebanyak 68\% penduduk dunia masih menggantungkan sistem pengobatan tradisional yang mayoritas menggunakan tumbuhan untuk penyembuhan penyakit dan lebih dari $80 \%$ penduduk dunia menggunakan obat herbal untuk meningkatkan vitalitas tubuh serta mendukung kesehatan. Kecenderungan masyarakat terhadap penggunaan tanaman obat ini semakin meningkat beberapa tahun belakangan, hal ini bukan hanya disebabkan minimnya efek samping yang ditimbulkan dibandingkan bahan kimia namun juga banyaknya senyawa bioaktif yang tidak dapat diwakili oleh senyawa sintesis meski dengan bantuan teknik kombinatorial kimia (Henkel, Brunne, H., \& Reichel, 1999). Namun pengelolaan dan pemakaian obat bahan alam untuk penangangan utama penyakit seringkali terhambat oleh kualitas bahan yang rendah dan tidak stabil (Xie \& Leung, 2009).

Salah satu tanaman obat yang dikenal secara luas oleh masyarakat Indonesia ialah Curcuma longa L. (kunyit). Kunyit atau kunir (C. longa) termasuk salah satu tanaman rempah dan obat yang biasa digunakan di negara Timur Tengah dan kawasan lain di Asia (Pribadi, 2009). Komponen aktif utama yang terdapat dalam kunyit yaitu kurkumin, demetoksikurkumin, bis-demetoksikurku-min, dan ar-turmeron (Prakash, Satyan, \& S.Majeed, 2003). Kualitas suatu senyawa dapat ditunjukkan dengan sifat bioaktivitasnya dan sifat tersebut dipengaruhi oleh komposisi kimia yang terkandung di 
dalamnya. Oleh sebab itu, diperlukan suatu teknik analisis yang mampu mengidentifikasi keragaman profil metabolit dalam suatu senyawa.

Dari berbagai teknik analisis yang ada, fingerprinting berbasis NMR merupakan pilihan yang sangat tepat karena NMR memiliki kisaran deteksi yang luas mencakup senyawa dari golongan non-polar sampai polar, dan preparasi sampel yang sederhana. NMR memiliki reprodusibilitas yang paling tinggi dibanding analisis kimia yang lain sehingga data yang telah diukur baik itu ekstrak obat herbal, senyawa standar atau referensi dapat dijadikan sebagai acuan dan menjadi database untuk analisis selanjutnya. Untuk keberhasilan analisis fingerprinting NMR ini maka perlu dilakukan optimasi dalam protokol penyiapan sampel dan metode baku pengukuran NMR. Oleh karena itu, tujuan dari penelitian ini adalah mengetahui pelarut yang paling optimum dan optimasi metode untuk mengekstraksi senyawa aktif pada rimpang kunyit dan senyawa yang terekstrak pada pelarut yang terpilih.

\section{Metodologi Penelitian}

\section{Preparasi sampel}

Rimpang kunyit yang digunakan dikoleksi dari Karanganyar kemudian dibersihkan dan dicuci dengan air mengalir dan mencegah kontaminasi yang dapat mempengaruhi mutu rimpang. Rimpang segera ditiriskan dengan rak pengering dan dibolak-balik secara periodik selama \pm 1 minggu untuk memastikan keseragaman pengeringan dan mencegah fermentasi. Untuk mempercepat proses pengeringan rimpang kunyit dirajang secara split (membujur untuk mengurangi terputusnya serat-serat yang didalamnya terdapat minyak atsiri) dengan ketebalan 4-5 mm (Prasetya \& Yuliani, 2014). Setelah dirajang rimpang kunyit kemudian dikeringkan dengan oven bersuhu $50^{\circ} \mathrm{C}$ selama 8-10 jam, kemudian diserbuk dan di lakukan freeze drying untuk menghilangkan kadar air.

\section{Analisis ${ }^{1} \mathrm{H}-\mathrm{NMR}$}

Sampel kering dalam tabung Eppendorf ditimbang $(50 \mathrm{mg})$ dan ditambahkan solvent ekstraksi dengan variasi tiga konsentrasi yang berbeda yaitu methanol- $d_{4} 100 \%, 70 \%$ dan $30 \%\left(750 \mu \mathrm{l} \mathrm{CD} \mathrm{OD}_{3}+750 \mu \mathrm{l} \mathrm{KH_{2 }} \mathrm{PO}_{4}\right.$ buffer dalam $\mathrm{D}_{2} \mathrm{O}$ ( $\mathrm{pH}$ 6.0). Sampel dihomogenisasi dengan vortex dahulu selama 1 menit di suhu ruang $\left(20-25^{\circ} \mathrm{C}\right)$ kemudian diekstraksi menggunakan ultrasonikator selama 15 menit di suhu ruang. Supernatan sebanyak $1 \mathrm{ml}$ dimasukkan ke tabung Eppendorf 1,5 ml. Kemudian sampel disentrifugasi pada kecepatan $10.000 \mathrm{~g}$ di suhu ruang selama 10 menit untuk mendapatkan supernatan yang jelas. Supernatan sebanyak $800 \mu \mathrm{l}$ dimasukkan kedalam tabung NMR $5 \mathrm{~mm}$, dan ditempatkan di suhu ruang selama setengah jam sebelum pengukuran NMR untuk menghindari shimming akibat perbedaan temperatur pada sampel dan setelahnya dapat dianalisis dalam spektroskopi H NMR.

\section{Analisis data ${ }^{1} \mathrm{H}-\mathrm{NMR}$}

Hasil spektra NMR dikonversikan ke bentuk yang sesuai untuk dilakukan analisis multivariat. Penelitian ini menggunakan software (Mestrelab) MNOVA v.11.0.4 untuk pengolahan data 1D NMR. Identifikasi metabolit dilakukan dengan perbandingan sinyal NMR dengan referensi senyawa atau dengan spektra satu dimensi. Pengukuran kandungan metabolit secara semikuantitatif dilakukan dengan membandingkan jarak sinyal metabolit yang dianalisis dengan sinyal standar solvent atau pergeseran kimia (chemical shift).

\section{Hasil dan Pembahasan}

Profiling metabolit berbasis NMR merupakan langkah awal analisis metabolit secara kualitatif dan kuantitatif.NMR memiliki kisaran deteksi yang luas mencakup senyawa dari golongan non-polar sampai polar, dan preparasi sampel yang sederhana serta memiliki reprodusibilitas yang paling tinggi dibanding analisis kimia yang lain sehingga data yang telah diukur baik itu ekstrak obat herbal, 
senyawa standar atau referensi dapat dijadikan sebagai acuan dan menjadi database untuk analisis selanjutnya. Untuk keberhasilan analisis fingerprinting NMR ini maka perlu dilakukan optimasi dalam protokol penyiapan sampel dan metode baku pengukuran NMR.

Pada persiapan sampel rimpang kunyit yang berasal dari wilayah Karanganyar diidentifikasi untuk kemudian dilakukan preparasi di laboratorium. Pada penelitian dilakukan sonikasi terhadap seluruh sampel selama 15 menit dengan Ultrasonicator LC 130.

Sonikator memberikan adanya lokal kavitasi pada senyawa atsiri, volatil atau semivolatil di dalam dinding sel tumbuhan, sehingga diharapkan meningkatkan jumlah senyawa bioaktif yang terekstraksi tanpa adanya pemanasan yang dapat merusak konformasi senyawa.

Dalam pengukuran sampel dilarutkan dalam pelarut yang tidak mengandung proton (salah satunya Metanol- $d_{4}$ ) yang memiliki sifat semipolar sehingga sesuai untuk mengekstraksi senyawa bioaktif terutama kurkumin pada rimpang kunyit, buffer fosfat untuk menstabilkan kondisi $\mathrm{pH}$ larutan agar dapat mencegah perubahan konformasi atau struktur beberapa senyawa bioaktif yang sensitif, 3-(trimethylsilyl)2,2,3,3-tetradeuteropropionic acid (TMSP- $d_{4}$ ) 0,01\% ditambahkan sebagai standar internal, dan dilarutkan dalam $\mathrm{D}_{2} \mathrm{O}$ untuk kuantifikasi metabolit dengan pelarut methanol-d4 berbagai konsentrasi (Kim, et al., 2011). Selain itu kurkumin dapat mengalami perubahan warna akibat perubahan $\mathrm{pH}$ lingkungan. Kurkumin berwarna kuning atau kuning jingga pada suasana asam,sedangkan dalam suasana basa berwarna merah. Kurkumin dalam suasana basaatau pada lingkungan $\mathrm{pH} 8,5-10,0$ dalam waktu yang relatif lama dapat mengalami proses disosiasi, kurkumin mengalami degradasi membentuk asamferulat dan feruloilmetan. Sehingga penting untuk menjaga kestabilan $\mathrm{pH}$ pada ekstrak kasar tersebut.

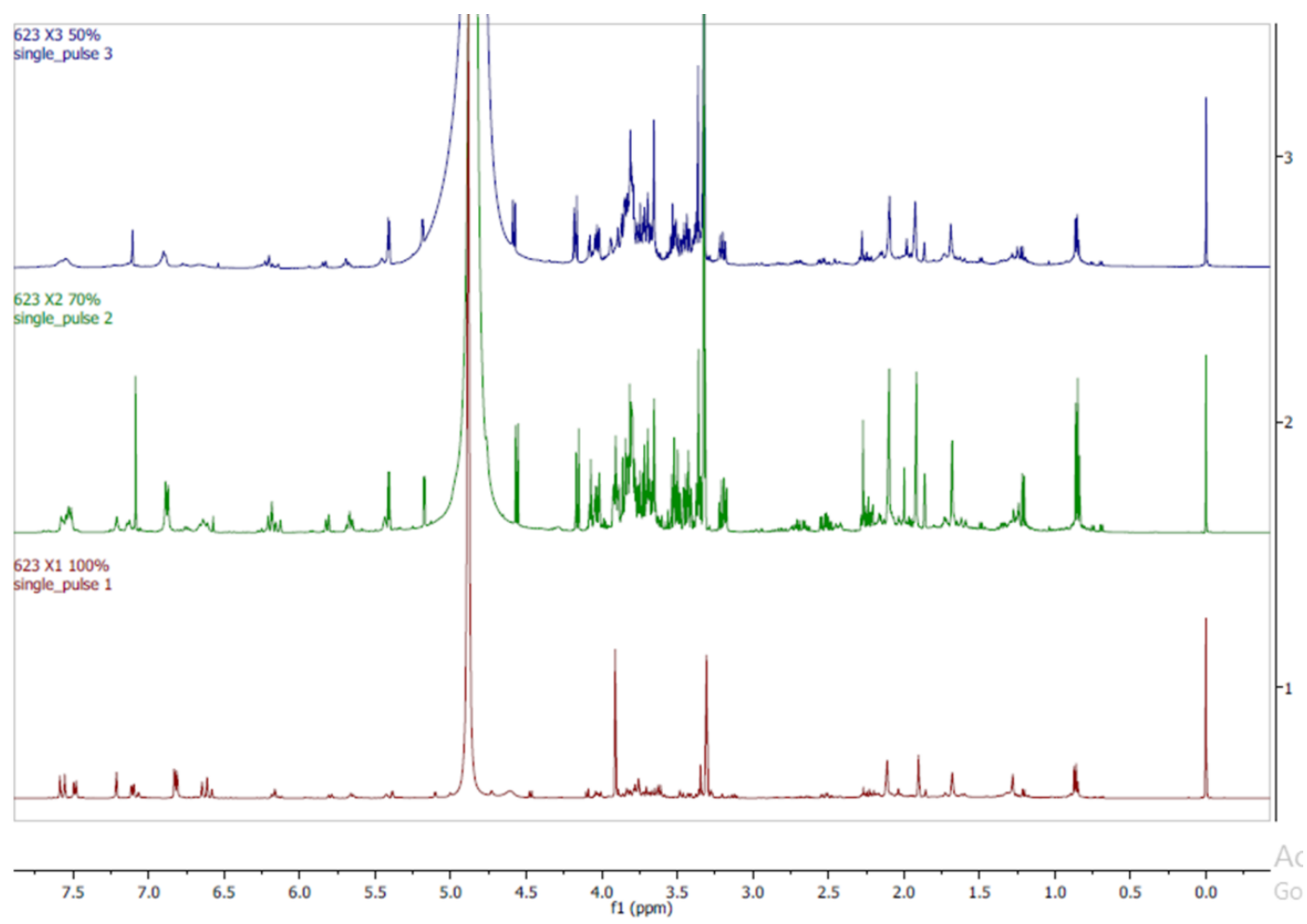

Gambar 1. Stack ${ }^{1} \mathrm{H}$ NMR $500 \mathrm{MHz}$ rimpang kunyit pada pelarut $\mathrm{CD}_{3} \mathrm{OD}$

Pada penelitian ini digunakannya protokol Dari hasil yang diperoleh berupa spektra ${ }^{1} \mathrm{H}$ ${ }^{1} \mathrm{H}$ NMR dengan pre-sat untuk menekan sinyal NMR rimpang kunyit pada pelarut methanol air dan meningkatkan resolusi spektra ${ }^{1} \mathrm{H}$ NMR. berbagai konsentrasi mengandung ratusan 
sinyal yang ditunjukan pada Gambar 1. Sinyal tersebut memperlihatkan keseluruhan jumlah metabolit yang terekstraksi oleh masing-masing pelarut sesuai polaritas atau karakteristik tiap metabolit. Konsentrasi absolut metabolit dapat dihitung dengan membandingkan intensitas puncak (peak)-nya dengan standard internal. Puncak diukur tidak berdasar posisi resonansi melainkan jarak geseran dari TMSP atau standar internal yang digunakan (chemical shift).

Dari stack ${ }^{1} \mathrm{H}$ NMR dapat dibagi tiga wilayah untuk profiling metabolit yaitu diperkirakan senyawa golongan aromatik terekstraksi pada chemical shift 5,75- 8,0 pm; senyawa golongan sakarida terekstraksi pada kisaran 2,75-5,75 ppm ; dan senyawa golongan asam amino dan asam lemak terekstraksi pada kisaran 0,5-2,75 ppm. Untuk kurkumin sebagai komponen bioaktif utama pada rimpang kunyit merupakan senyawa golongan aromatik sehingga terekstraksi pada wilayah 6,5-7,75 ppm.

Senyawa yang berjumlah sedikit sulit dideteksi karena lemahnya sinyal serta adanya kemungkinan tumpukan puncak (peak) dalam satu area. Sehingga untuk mendeteksi seluruh sinyal secara lengkap menghabiskan waktu banyak meski dengan deteksi NMR dua dimensi. Seluruh daftar metabolit yang diduga terekstraksi dalam tiap pelarut (Tabel 1) diidentifikasi cepat menggunakan software MNOVA v.11.0.4 dan dibandingkan dengan referensi chemical shift NMR yang telah diketahui terekstraksi pada kondisi yang sama (Kim, Choi, \& Verpoorte, 2010).

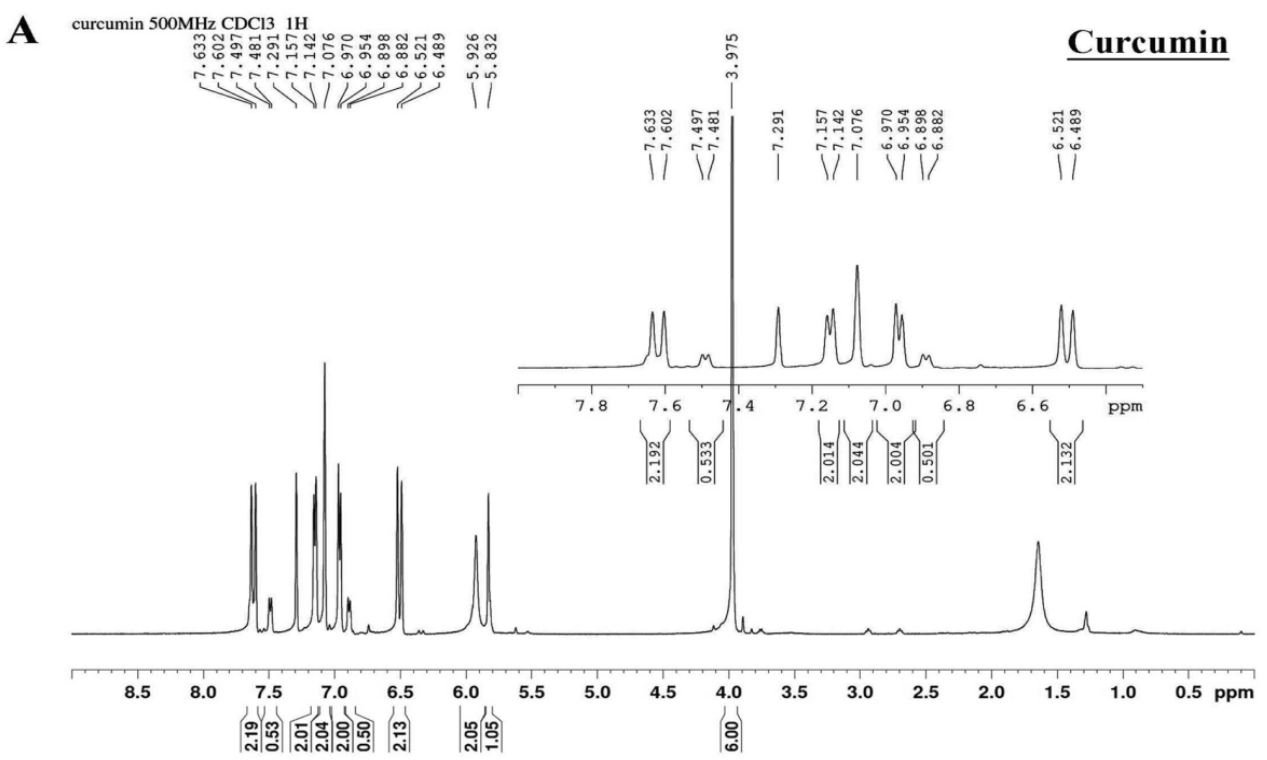

Gambar 2. Spektra spektroskopi ${ }^{1} \mathrm{H}$ NMR $500 \mathrm{MHz}$ kurkumin pada pelarut $\mathrm{CDCl}_{3}$

Untuk langkah selanjutnya perlu dilakukan identifikasi sinyal senyawa yang belum diketahui dengan pengukuran dua dimensi. Sehingga didapatkan informasi berupa plot chemical shift versus coupling constants. 


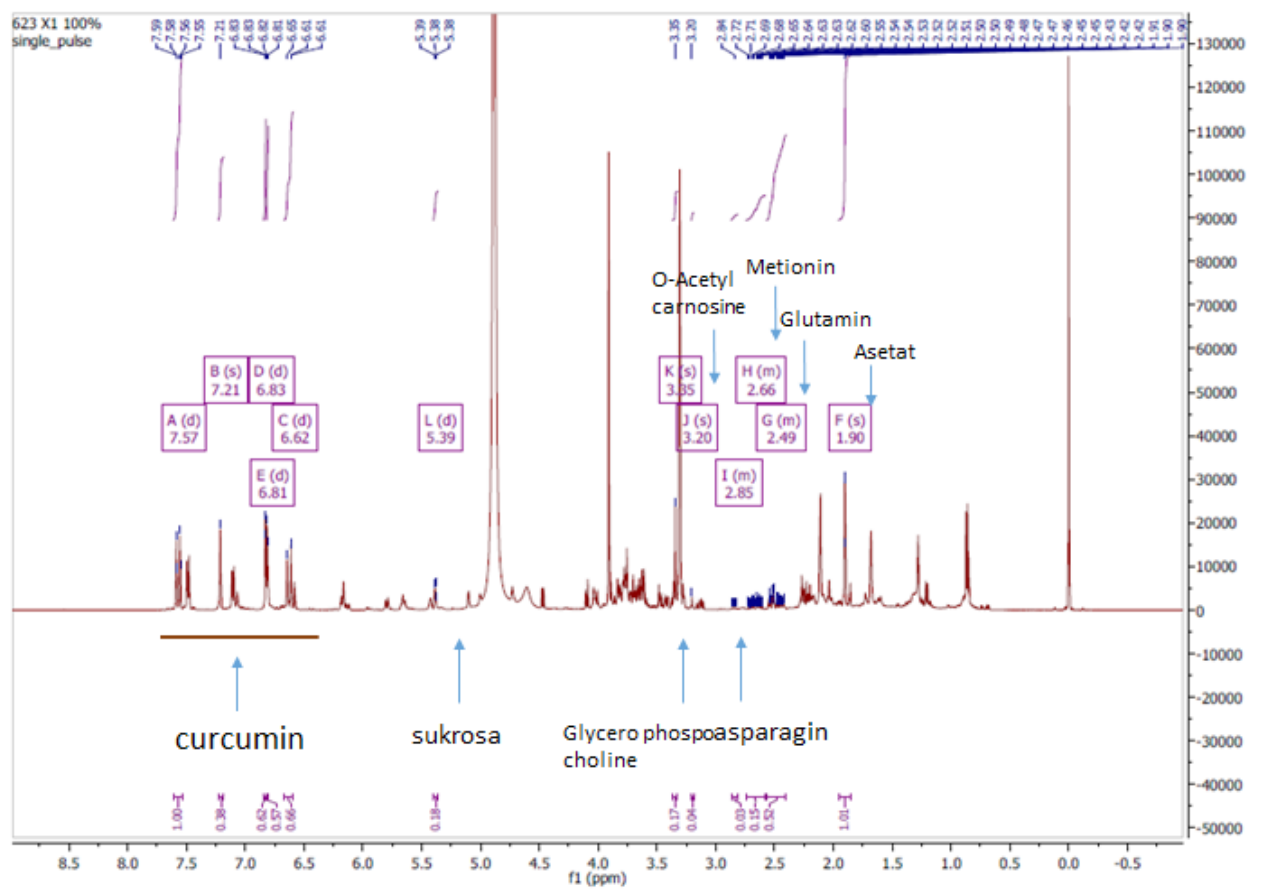

Gambar 3. Spektra spektroskopi ${ }^{1} \mathrm{H}$ NMR rimpang kunyit dengan pelarut $100 \% \mathrm{CD}_{3} \mathrm{OD}$

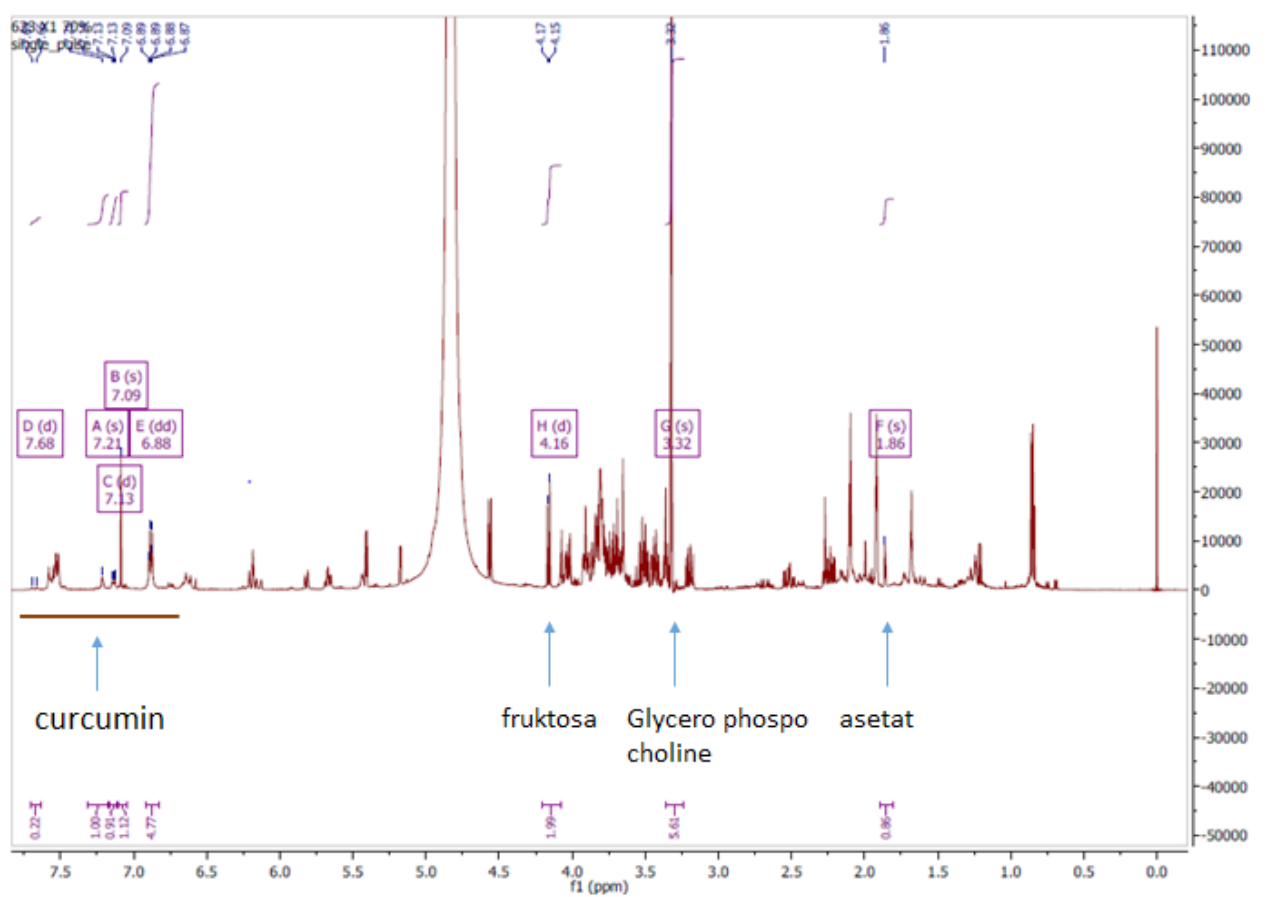

Gambar 4. Spektrum spektroskopi ${ }^{1} \mathrm{H}$ NMR rimpang kunyit dengan pelarut $70 \% \mathrm{CD}_{3} \mathrm{OD}$

Spektra hasil ${ }^{1} \mathrm{H}$ NMR rimpang kunyit dengan pelarut $100 \% \mathrm{CD}_{3} \mathrm{OD}$ (Gambar 3.) menunjukan senyawa kurkumin terekstrak lebih baik melalui perbandingan geseran kimia (chemical shift) dan tinggi garis integral dengan referensi yang ada (Gambar 3). Signal kurkumin muncul pada geseran kimia 7,$52 ; 7,21 ; 6,83$;
6,$81 ;$ dan $6,62 \delta$ (ppm), namun senyawa golongan sakarida tidak terekstraksi lebih baik dibanding konsentrasi pelarut lainnya yakni hanya sukrosa pada 5,39 ppm. Senyawa golongan asam amino dan asam lemak yang diduga muncul diantaranya glycerophospocholine, asparagin, O-Acetyl carnosine, metionin, 
glutamin dan asetat. Namun dari grafik terlihat banyaknya sinyal yang tumpang tindih pada satu area (crowded in one area), sehingga masih adanya senyawa yang tidak teridentifikasi.

Spektra hasil ${ }^{1} \mathrm{H}$ NMR rimpang kunyit dengan pelarut $70 \% \mathrm{CD}_{3} \mathrm{OD}$ (Gambar 4.) menunjukan adanya beberapa sinyal senyawa kurkumin yang terekstrak melalui perbandingan geseran kimia (chemical shift) yang telah diketahui, namun ditinjau dari tinggi garis integral tidak lebih baik dibanding hasil ekstraksi pelarut $100 \%$. Signal kurkumin muncul pada geseran kimia 7,68; 7,21;7,13; 7,09 dan 6,88 $\delta(\mathrm{ppm})$, sementara senyawa golongan sakarida terlihat terekstraksi lebih banyak dibanding konsentrasi pelarut lainnya yakni fruktosa pada 4,16 ppm serta sinyal lainnya yang tumpang tindih pada satu area sehingga belum dapat teridentifikasi. Senyawa golongan asam amino dan asam lemak yang diduga muncul berupa glycerophospocholine dan asetat.
Spektra hasil ${ }^{1} \mathrm{H}$ NMR rimpang kunyit dengan pelarut 50\% $\mathrm{CD}_{3} \mathrm{OD}$ (Gambar 5.) menunjukan tidak terdeteksinya sinyal kurkumin, sementara senyawa golongan sakarida terlihat lebih banyak terekstraksi yakni fruktosa pada 4,02 ppm serta sinyal lainnya yang tumpang tindih pada satu area sehingga belum dapat teridentifikasi. Senyawa golongan asam amino dan asam lemak yang diduga muncul hanya asetat.

Hasil ekstraksi pelarut Metanol- $d_{4} 100 \%$ mampu mengekstrak kurkumin, senyawa golongan aromatik yang cenderung memiliki polaritas rendah lebih baik. Hal ini terkait sifat Metanol- $d_{4}$ sebagai pelarut universal yang mampu mengekstrak senyawa polaritas rendah hingga tinggi serta kesesuaian polaritas-nya (asas like dissolve like) terhadap metabolit primer golongan sakarida dan asam amino maupun metabolit sekunder seperti golongan fenolik atau kurkuminoid (Tabel 1).

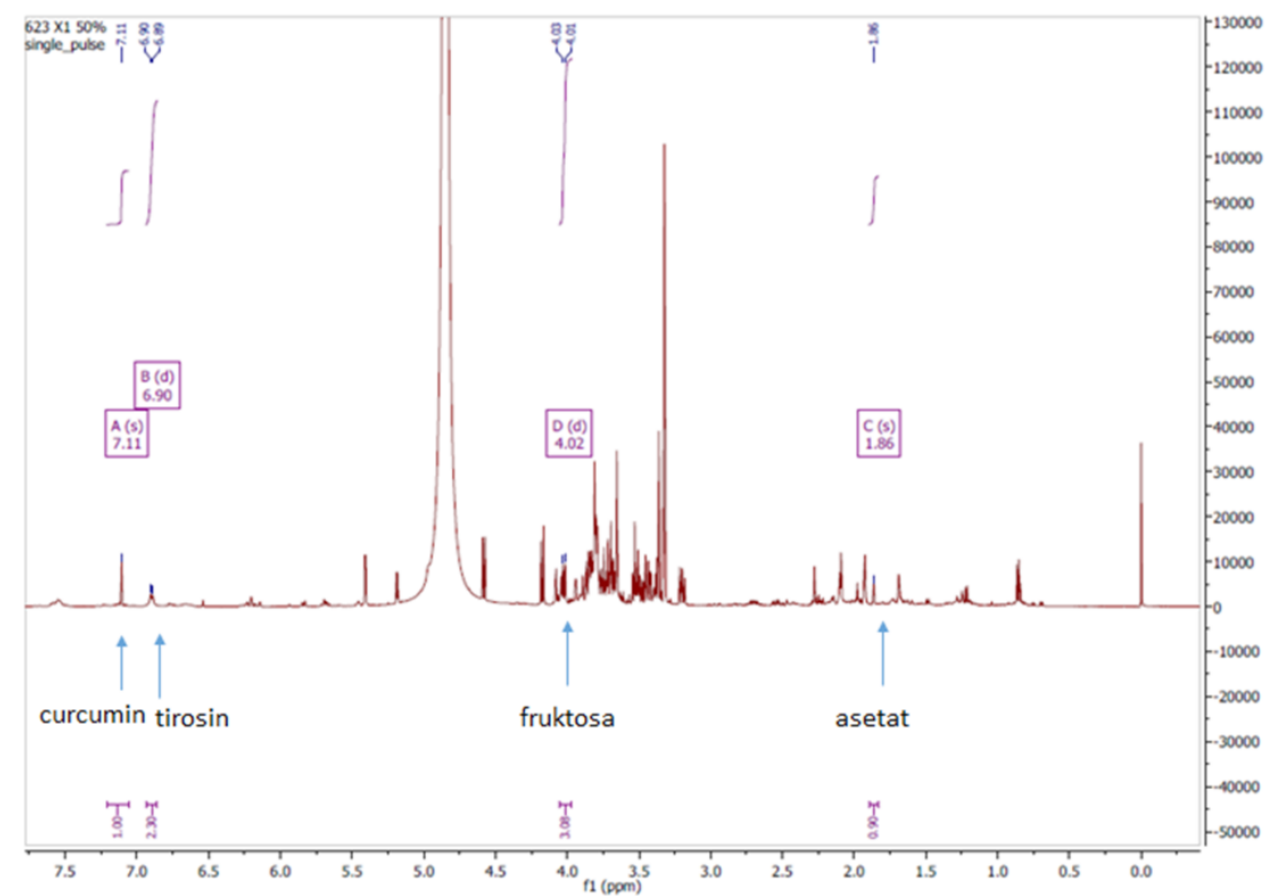

Gambar 5. Spektra spektroskopi ${ }^{1} \mathrm{H}$ NMR rimpang kunyit dengan pelarut $50 \% \mathrm{CD}_{3} \mathrm{OD}$

Ketika $\mathrm{CD}_{3} \mathrm{OD}$ atau methanol dilarutkan Senyawa yang diprediksi terekstrak oleh pelarut dalam $\mathrm{D}_{2} \mathrm{O}$ menyebabkan meningkatnya Metanol- $d_{4}$ pada rimpang kunyit dengan polaritas solvent sehingga tidak cukup optimal spektroskopi ${ }^{1} \mathrm{H}$ NMR $500 \mathrm{MHz}$. untuk mengekstraksi senyawa non-polar. 
Tabel 1. Prediksi metabolit terdeteksi ${ }^{1} \mathrm{H}$ NMR rimpang kunyit pada berbagai konsentrasi pelarut

\begin{tabular}{|c|c|c|c|c|c|c|}
\hline No & Nama & $\begin{array}{c}\text { Chemical shift } \\
(\delta, \text { ppm })\end{array}$ & $\begin{array}{c}\text { Jenis } \\
\text { spektra* }\end{array}$ & $\begin{array}{c}100 \% \\
\text { solvent }\end{array}$ & $\begin{array}{c}70 \% \\
\text { solvent }\end{array}$ & $\begin{array}{c}50 \% \\
\text { solvent }\end{array}$ \\
\hline 1 & Curcumin & $\begin{array}{c}7.68 \\
7.57 \\
7.21 \\
7.09-7.11 \\
7.13 \\
6.81-6.83 \\
6.88-6.9 \\
6.62\end{array}$ & $\begin{array}{l}\mathrm{d} \\
\mathrm{d} \\
\mathrm{s} \\
\mathrm{s} \\
\mathrm{d} \\
\mathrm{d} \\
\mathrm{d} \\
\mathrm{d}\end{array}$ & $\begin{array}{c}- \\
\text { Ada } \\
\text { Ada } \\
- \\
- \\
\text { Ada } \\
\text { Ada } \\
\text { Ada }\end{array}$ & $\begin{array}{c}\text { Ada } \\
- \\
\text { Ada } \\
\text { Ada } \\
\text { Ada } \\
- \\
\text { Ada } \\
-\end{array}$ & \\
\hline 2 & Acetate & $1.86-1.9$ & d & Ada & Ada & Ada \\
\hline 3 & Glutamine & 2.45 & $\mathrm{~m}$ & Ada & - & - \\
\hline 4 & Methionine & 2.7 & $\mathrm{~m}$ & Ada & - & - \\
\hline 5 & Asparagine & 2.85 & $\mathrm{~m}$ & Ada & - & - \\
\hline 6 & $\begin{array}{l}0 \text {-acethyl } \\
\text { carnosine }\end{array}$ & 3.2 & s & Ada & - & - \\
\hline 7 & $\begin{array}{l}\text { Glycero } \\
\text { Phospho } \\
\text { Coline }\end{array}$ & $3.32-3.35$ & $s$ & Ada & Ada & - \\
\hline 8 & Fructose & $\begin{array}{c}4.02-4.03 \\
\quad 4.16\end{array}$ & d & - & Ada & Ada \\
\hline & Sucrose & 5.39 & d & Ada & - & - \\
\hline 9 & Tyrosine & 6.9 & d & - & - & Ada \\
\hline
\end{tabular}

\section{Simpulan}

Konsentrasi Methanol-d4 ( $\left.\mathrm{CD}_{3} \mathrm{OD}\right)$ $100 \%$ mengekstraksi kurkumin lebih baik dibandingkan pelarut lainnya. Pelarut $\mathrm{CD}_{3} \mathrm{OD}$ mampu mengekstrak senyawa golongan sakarida berupa sukrosa, asam amino serta asam lemak berupa metionin, glutamin, asparagin. asetat, O-Acetyl carnosine, dan glycero phospo choline

\section{Ucapan Terimakasih}

Penelitian ini dibiayai oleh Penelitian Unggul Perguruan Tinggi Kemenristekdikti tahun anggaran 2107 kepada Y.A.P.

\section{Daftar Pustaka}

Henkel, T., Brunne, R., H., M., \& Reichel, F. (1999). Statistical Investigation into the Structural Complementarity of Natural Products and Synthetic Compounds. Angew. Chem., Int. Ed, Vol 38(5): p 643-647.

Kim, E., Kwon, J., Park, S., Park, C., Seo, Y., Shin, H., . . Hwang, D. R. (2011). Metabolite profiling of Angelica gigas from different geographical origin using 1H NMR and UPLC-MS analyses. J Agric Food Chem., Vol 59: p 8806-8815.

Kim, H., Choi, Y., \& Verpoorte, R. (2010). Protocol NMR-based metabolomic analysis of plants. Nature Publishing Group, Vol 5(3): p 536-548.

Prakash, L., Satyan, K., \& S.Majeed. (2003). Multifunctional Ingredients. The Novel Face of Natural, Cosmetics and Toiletries, Vol 118(11):p 41-46.

Prasetya, D., \& Yuliani, S. (2014). Aktivitas Ekstrak Rimpang Remulawak (Curcuma xanthorrhiza 
roxb.) pada Radial Arm Maze dan Pasive Avoidance Test Tikus Model Demensia. Pharma冈iana, 4(2):157-164, Vol 4(2):p 157-164.

Pribadi, E. (2009). Pasokan dan permintaan tanaman obat Indonesia serta arah penelitian dan pengembangannya. Perspektif. 8: 52-64. Perspektif, Vol 8: p 52-64.

Xie, P., \& Leung, A. (2009). Understanding the traditional aspect of Chinese medicine in order to achieve meaningful quality control of Chinese materia medica. J Chromatogr A, Vol 1216(11): p 1933-1940. 